\title{
Glycerol kinase deficiency, juvenile form
}

INSERM

\section{Source}

INSERM. (1999). Orphanet: an online rare disease and orphan drug data base. Glycerol kinase deficiency, juvenile form. ORPHA:284411

Juvenile glycerol kinase deficiency (GKD) is an uncommon form of GKD (see this term) characterized by Reye-like clinical manifestations including episodic vomiting, acidemia, and disorders of consciousness. 